Vol. 2, No. 1, Juni 2021

\title{
SPEKTA
}

Jurnal Pengabdian Kepada Masyarakat : Teknologi dan Aplikasi

Journal homepage :

http://journal2.uad.ac.id/index.php/spekta

\section{PREVALENCE AND FORMS OF ONLINE HARASSMENT AMONG UNDERGRADUATES OF A NIGERIAN UNIVERSITY}

\section{Mulikat Ladi A. Mustapha*, Shuaib Abolakale Muhammed, Faith Folusho Olowoniyi}

Department of Counsellor Education, Faculty of education, University of Ilorin, Nigeria

\section{ARTICLE INFO}

Received : October, 2020

Revised : November, 2020

Accepted : December, 2020

Keywords:

Cyberbullying;

Harassment;

Prevalence;

Online harassment,

Undergraduates.

\begin{abstract}
The upsurge in accessing and utilizing the internet and social networking sites for social activities predisposes adolescents and young adults globally to online harassment, Nigerian undergraduates inclusive. The impacts of online harassment have attracted many research interests, especially in the developed world and the dearth of inquiries among Nigerian undergraduates. This work inquired about the prevalence and forms of online harassment perpetrated by undergraduates in a Nigerian university. A descriptive research design was adopted, data were amassed utilizing a three-sectioned self-report form administered on a sample of 420 undergraduates. The selection of the sample was made following a multistage procedure. Percentage and univariate analysis techniques were used for data analysis. The result of the inquiry revealed widespread online harassment among the undergraduates of the university. All the forms of online harassment assessed were perpetrated; dog pilling topped the list (63.1\%), followed by trolling (44.0\%). The high rate of occurrence demands the urgent attention of the university authority, professionals across relevant fields should create awareness; the need to develop interventions and policies to deal with online harassment is obvious.
\end{abstract}

\section{INTRODUCTION}

Assessing the prevalence of online harassment is essential because it affects student's social, emotional, psychological, and physical lives. Students, especially undergraduates, are seen as tomorrow's leaders in every community, which means that they are the human resources of a nation that is also seen as the nation's growth engine (Muhinat, 2020). For some decades now, the use of the internet has been very rampant, and it has been very operative in terms of communication, enlightenment, and education. With the invention of different social media such as Facebook, WhatsApp, YouTube, 2go, Skype, WeChat, Twitter, Instagram, and many more, the social networking interest of undergraduates has increased across the Nigerian nation as it did globally.

\footnotetext{
* Corresponding author.

E-mail address: mustapha.mla@unilorin.edu.ng

https://doi.org/10.12928/J.spekta.v2i2.2972
} 
Vol. 2, No. 1, Juni 2021

The era of the industrial revolution 4.0 that is happening today is forcing all things into information technology (Khairi et al. 2020). Social networking sites have increased over the years, so their level of access and usage. For instance, Ericsson.com ConsumerLab (2019) reported that utilization of (Facebook, Instagram, and WhatsApp) has singly propelled from 1.3 billion monthly users in 2014 to 2.5 billion in 2018 . The report also reflected the upsurge in the duration of time expended on social media platforms from 30 minutes daily in 2014 to 47 minutes in 2018. The use of WhatsApp is widely spread across the globe; Andjelic (2019) affirmed that as of 2017, there were 1.5 billion vigorous clients who utilize WhatsApp in close to two hundred nations, more than five hundred million explore WhatsApp status every day with more than 65 million text post each day. Elias and Magdalena (2019) reported the increase in Gmail users from 1 billion people in 2016 to 1.5 billion users in 2019 and 2.5 billion users to use Email. Following these statistics clearly shows that using the internet for social, economic, and educational purposes is immensely beneficial to people; the ease of utilization in realizing many goals has continued to favor its use among the human population.

Despite the considerable benefit, Ericsson ConsumerLab Insight report (2019) claimed that new technology had exposed users to numerous challenges, including privacy invasion, intrusive postings, compulsive use of the internet, phishing, cyberbullying, and harassment. The new technologies and internet have offered increasing anonymous opportunities, powerful avenues, and empowerment to individuals to intimidate and harass their victims on a larger scale by reaching an evergrowing global audience. Internet users have also grown in Nigeria as it occurs in other nations of the world.

It has been reported that more than 174 million Nigerian active internet users subscribed monthly to technology data while there are more than 259 million connected internet lines (Nigeria Communication Commission, 2019). Kennedy and Taylor (2010); Nwachukwu and Onyenankeya (2017) found that a more significant percent $(98 \% \& 75 \%)$ of the sampled university students utilized their communication devices for social activities more than academic purposes. Over $33 \%$ of the sampled students reported maintaining public profiles containing their data (Kennedy and Taylor 2010). This situation could expose them to the risk of online harassment even by strangers. Online harassment has many components, as pointed out by researchers.

For instance, Geach and Haralambous (2009) stated that online harassment is an inclusive phrase that spans an array of conduct. These consist of conveying offensive, frightening or indecent electronic correspondence via various information exchange systems like networked social platforms; haunting users on personal websites, mimicking other personalities online through the fabrication of fictitious biographies; or frequently posting irrelevant and irrelevant and disruptive messages to a particular user. Feinberg and Robey (2009) further added to this definition by including online activities such as stalking, threats, sexual harassment, impersonation, humiliation, trickery, and exclusion. Feinberg and Robey (2009) further this description by including online acts like an ambush, coercion, bullying, unwanted sexual advance, portraying other personalities, disgrace, deceit, and bars. Software Freedom Law Centre (SFLC Report, 2016) depicts online harassment as a variety of restrictions that oblige individuals to participate in online conversation. The report, however, was limited to the aspects of harassment that were dialogue-based. In contrast, online harassment in this study has a broader scope to cover different forms of online harassment. 
Vol. 1, No. 2, Juni 2021

Similarly, online harassment can be perpetrated in various means or forms. These include name-calling, trolling, doxing, physical threats, stalking, cyberbullying, and sexual harassment (Duggan, 2017). Other acts of online harassment, as identified by other researchers, include impersonation or identity theft, swatting, dog pilling, hate speech, catfishing, trickery, and exclusion. Catfishing is a situation when a person creates a fake online profile to seduce someone (Harris, 2013) fraudulently. The various forms of online harassment are experienced across the globe.

Online harassment is a worldwide phenomenon. The reported rate of occurrences ranges from $4 \%-41 \%$ across age, gender, countries, and study period. The wide variation in the range of occurrences is adduced to differences in the terminologies used by different researchers during their inquiries. In some studies, it is referred to as cyberbullying; some used online aggression, to list a few. The population of the study samples varies from children to adolescents and adults. In addition, differing time frames are adopted in various studies; some studies inquired about the rate of occurrence within a specific time frame. Others did not measure the period of occurrence in the assessment. Some of the studies focused on perpetration, while others considered victimization experienced by internet users.

On perpetration of online bullying, Ybarra et al. (2007) reported 29\% perpetration of online harassment at least once a year. MacDonald and Roberts-Pittman (2010) found 8\% prevalence of online harassment; Zacchill and Valerio (2011) found $3.6 \%$ of cyberbullying perpetration; Novo, Pereira, and Matos (2014) found $33.3 \%$ of the respondents perpetrated any form of online harassment. The different forms of online harassments impact the victims, as well as the perpetrators in various spheres; economic, emotional, and in their behavior as reported by arrays of researchers (Henry and Powell, 2016; Englander, 2017; Jenaro et al., 2017, Maltby, 2017; Myer and Cowie, 2017; Ofcom, 2017). Because of the preceding, there is a great need to investigate how common online harassment is and the forms perpetrated by university undergraduates to determine intervention strategies. It is also pertinent to consider how some variables impact respondent's expression on the occurrence and forms of online harassment perpetrated, hence the need to review past work.

Considering the impacts of moderating variables of age, gender, religion, class level, and marital status on the prevalence and forms of online harassment perpetration, reports of inquiries were inconsistent. Kowalski and Limber (2007) reported that females are frequently involved in online harassment than males, while Novo, Pereira, and Matos (2014) found that more boys agreed to harass others than girls. On the level of education, Novo et al. (2014) found a difference in the percentage of adolescents at various levels of education who perpetrated online harassment.

On religious differences, Barlow and Awan (2016) identified various researches and documents (Hall, 2013; United Kingdom home Office, 2014; Awan and Zampi, 2015) emphasizing increasing rate of online harassment experienced by individuals based on their religion, most especially people of the Islamic faith. It is in line with the assertion of Chakraborti and Garland (2015) that online harassment can be channeled to individuals based on their religion, race, ethnic background, gender, age, disabilities, sexual identity, physical condition, among others. None of the researchers focuses on differences in the level of perpetration based on religion.

Universities worldwide have ceaselessly been improving the ICT facilities within their campuses to facilitate effective teaching, learning, and research activities, giving them opportunities to utilize the internet for their various activities. The 
Vol. 2, No. 1, Juni 2021

universities in Nigeria are not exempted in this stride despite their limited resources. The students who are well versed in the use of electronic media can hardly do without being online daily for social and academic purposes. Hence their risk of predisposes to online harassment perpetration and victimization. In a study conducted by Mustapha and Muhammed (2017), it was revealed that $6.9 \%$ of the sampled university undergraduates were addicted to the internet, while $30.7 \%$ were prone to addiction. These pointers suspect incidences of online harassment of various forms, which have consequences on the perpetrators and victims.

The impacts of online harassment are not limited to a particular group, and it cut across age, gender, status, political class, religious institutions, and institutions of learning. Companies, as well as professionals, are not left out. The incidence has become increasingly worrisome; this has led to the ninth assembly in Nigeria deliberating on a bill proposing the death penalty for hate speech which is a subset of online harassment since most of them are conveyed through social media and e-devices. Studies conducted on issues surrounding online harassment are majorly foreign-based. Those conducted in Nigeria mainly were on cyberbullying occurrence among in-school adolescents. It was the gap filled by this study.

The main aim of the study is to find out the prevalence and forms of online harassment perpetrated by university undergraduates. The study also examined whether the variables of age, class level, gender, marital status, and religion influence respondents' views on the occurrence and variety of online harassment committed by the undergraduates. The central questions raised and answered in the study are:

1. How common is online harassment among these university undergraduates?

2. What are the various forms of online harassment perpetrated by university undergraduates?

Based on the goal of the inquiry, the following null hypotheses were tested during this investigation:

Ho1: Age, class level, gender, marital status, and religion would not significantly influence undergraduates' expression on the prevalence of online harassment they perpetrate

Ho2: Age, class level, gender, marital status, and religion would not significantly influence undergraduates' expression on the forms of online harassment perpetrated

\section{RESEARCH METHOD}

The survey method of research was utilized to gather data on undergraduates' views regarding the prevalence and forms of online harassment perpetrated. The University of Ilorin has 15 faculties, with undergraduates over 53,000 (Annual Report, 2018/19). In the selection of the faculties, the researchers made use of a simple random sampling technique to select (420) respondents (163 females and 257 males) which consist of 247 respondents from 15-20 years old, 146 respondents from 21-25 years old, and 27 respondents above 25 years. All of them are from eight faculties, namely Faculty of Education, Social Sciences, Environmental Sciences, Engineering and Technology, Management Sciences, Agriculture, Communication and Information Sciences and Law.

A three-part questionnaire titled "Prevalence and forms of Online Harassment" was utilized in amassing data for this study. Section A entails personal details of the 
Vol. 1, No. 2, Juni 2021

students such as Gender, Religion, Marital Status, Age, and Class Levels. In contrast, section $\mathrm{B}$ focuses on the incidence of online harassment, and section $\mathrm{C}$ focuses on the forms of online harassment. In all the sections, simple and straightforward instructions were given to aid the respondents in understanding the questionnaire's content and aiding the adequate filling of the questionnaire. Sections B and C consist of close-ended items which give respondents options in making their choice. Option for the items includes agreeing and disagree.

Five experts in guidance and counseling did the content validity of the instrument. Corrections and suggestions made were affected, and the final draft was adjudged valid. In determining the reliability of the questionnaire, a test re-test technique was used. Twenty respondents were given the same instrument twice at an interval of four weeks, consequent to which the two results obtained were recorded and compared using the Pearson Product Moment Correlation coefficient formula. The reliability coefficient calculated was 0.94 , which is closer to 1 . It was therefore concluded that the instrument is reliable. The data collected were collated and scored accordingly. The sections $\mathrm{B}$ and $\mathrm{C}$ were scored using a two-point Likert-type scaling of agree 2 points, disagree 1 point.

For the analysis of data, descriptive average counting was used and a simple percentage count in handling gender, religion, age, marital status, and level. Frequency count and the percentage of respondents who ticked each item were analyzed on the prevalence and forms of online harassment expressed by the university undergraduates. A univariate analysis was adopted in finding the significant difference in the prevalence of online harassment likewise on the forms of online harassment.

\section{RESULTS AND DISCUSSION}

Answering the research questions below.

Research Question 1: How common is online harassment among undergraduates?

Table 1 presents the expression of the undergraduates on the prevalence of online harassment. The findings revealed that online harassment is common among university undergraduates. Many respondents (ranging from 63.6 to $94.0 \%$ ) affirmed all the items indicating the prevalence of online harassment. Suppose the minor percentage to affirm the occurrence was almost two-third. In that case, it shows that online harassment is a common phenomenon in Nigerian universities, just like it is in another developed world, as revealed by previous studies (Novo et al., 2010; Duggan, 2017) that reported a high rate of victimization. The mode of framing the items could be responsible for the affirmative response from a considerable percentage of respondents; the items were framed to determine whether online harassment occurred or not; hence, most of the students who witnessed experienced or perpetrated online harassment concur that it is a common phenomenon. Also, the way the items were framed to depict the behaviors that entail online harassment aided undergraduates' understanding of what connotes online harassment and facilitated their responses.

Table 1. Prevalence of online harassment as expressed by the respondents

\begin{tabular}{cccccc}
\hline $\begin{array}{c}\text { Item } \\
\text { No. }\end{array}$ & \multicolumn{2}{c}{ In my institution: } & $\begin{array}{c}\text { Agree } \\
\text { F (\%) }\end{array}$ & $\begin{array}{c}\text { Disagree } \\
\text { F (\%) }\end{array}$ & Rank \\
\hline 1 & Online & harassment is common among & $381(90.7)$ & $39(9.3)$ & $3^{\text {rd }}$ \\
\hline
\end{tabular}


Vol. 2, No. 1, Juni 2021

\section{students}

It is common among students to make use of other person's identity to

$345(82.1) \quad 75(17.9) \quad 6^{\text {th }}$ communicate on social media

The act of posting provocative comments about others is common

$393(93.6) \quad 27(6.4) \quad 2^{\text {nd }}$
among students

False location usage is common among students

Unlawfully monitoring of an individual

via social media to hurt the individual do happens

Students give false information such as fire outbreak via the internet

Obtaining and using private information of an individual from social media as a form of asset do occur

Posting nude pictures of an ex-partner for revenge do occur

Slandering on social networks is rampant among students

Individuals you do not know always solicit for a sexual relationship

It is common for acquaintance to make sexual proposal online

One usually experiences false accusation via social media

The acts of posting comments that stirs

up an argument on social networks occur

$366(87.1) \quad 54(12.9) \quad 4^{\text {th }}$

$286(68.1) \quad 134(31.9) \quad 12^{\text {th }}$

$267(63.6) \quad 153(36.4) \quad 14^{\text {th }}$

$316(75.2) \quad 104(24.8) \quad 9^{\text {th }}$ among students

False gender usage is common among students

15 The threat is always experienced online

$276(65.7) \quad 144(34.3) \quad 13^{\text {th }}$

$361(86.0) \quad 59(14.0) \quad 5^{\text {th }}$

$309(73.6) \quad 111(26.4) \quad 10^{\text {th }}$

327(77.9) $\quad 93(22.1) \quad 8^{\text {th }}$

$335(79.8) \quad 85(20.2) \quad 7^{\text {th }}$

$395(94.0) \quad 25(6.0) \quad 1^{\text {st }}$

Research Question 2: What are the various forms of online harassment perpetrated by University undergraduates?

Table 2 shows the distribution of respondents' expression on the various forms of online harassment perpetrated. The University undergraduates perpetrated all the forms of online harassment assessed in this inquiry; dog pilling being mostly perpetrated $(63.1 \%)$ and cyberstalking been the minor form of online harassment perpetrated $(17.9 \%)$. The findings reflect what transpired when live programs were conducted on radio and television stations where members of the public could comment on the topic of discussion. Some callers make unfriendly, rude, and nasty comments directed to guests rather than making their views known. It is also glaring that online harassment that ranked first was also in agreement with the first item agreed to be prevalent. The findings are in line with previous studies (Ybarra et al., 2007; Novo et al., 2014) that examined the perpetration of online harassment, even if it was once in a 
SPEKTA

Jurnal Pengabdian Kepada Masyarakat : Teknologi dan Aplikasi

Vol. 1, No. 2, Juni 2021

year, and different forms of online harassments. Similarly, the study revealed that $21.0 \%$ perpetrate cyberbullying, a closer figure to Olumide et al. 2015. The findings, however, are not following that of MacDonald and Roberts- Pittman (2010); Zachilli and Valerio (2011).

Table 2. Showing percentage of respondents on the Various Forms of Online Harassment

\begin{tabular}{|c|c|c|c|c|}
\hline $\begin{array}{l}\text { Item } \\
\text { No. }\end{array}$ & As an undergraduate, I: & $\begin{array}{l}\text { Agree } \\
\text { F (\%) }\end{array}$ & $\begin{array}{c}\text { Disagree } \\
\text { F }(\%)\end{array}$ & Rank \\
\hline 1 & slander other people online & $109(26.0)$ & $311(74.0)$ & $11^{\text {th }}$ \\
\hline 2 & solicit for sex online & $94(22.4)$ & $326(77.6)$ & $14^{\text {th }}$ \\
\hline 3 & $\begin{array}{l}\text { make use of another person's pictures in } \\
\text { order to achieve a particular goal, such as } \\
\text { making a particular person fall in love } \\
\text { with me }\end{array}$ & $125(29.8)$ & $295(70.2)$ & $7^{\text {th }}$ \\
\hline 4 & $\begin{array}{l}\text { pretend to be another individual in order } \\
\text { to use their identities }\end{array}$ & $118(28.1)$ & $302(71.9)$ & $10^{\text {th }}$ \\
\hline 5 & $\begin{array}{l}\text { post off-topic messages which do not } \\
\text { tally with a post in an online community } \\
\text { for fun }\end{array}$ & $185(44.0)$ & $235(56.0)$ & $2^{\text {nd }}$ \\
\hline 6 & $\begin{array}{l}\text { post-off-topic messages just because I } \\
\text { can afford a data plan }\end{array}$ & $136(32.4)$ & $284(67.6)$ & $5^{\text {th }}$ \\
\hline 7 & $\begin{array}{l}\text { stand against the opinion of others online } \\
\text { if it does not suit my beliefs }\end{array}$ & $265(63.1)$ & $155(36.9)$ & $1^{\mathrm{st}}$ \\
\hline 8 & $\begin{array}{l}\text { post unfriendly comments at times to } \\
\text { some particular post }\end{array}$ & $168(40.0)$ & $252(60.0)$ & $3^{\text {rd }}$ \\
\hline 9 & threaten people often online & $88(21.0)$ & $332(79.0)$ & $16^{\text {th }}$ \\
\hline 10 & $\begin{array}{l}\text { monitor the activities of some people in } \\
\text { order to cause fear and anxiety in them }\end{array}$ & $81(19.3)$ & $339(80.7)$ & $17^{\text {th }}$ \\
\hline 11 & $\begin{array}{l}\text { attack people online who post about } \\
\text { religious topics }\end{array}$ & $123(29.3)$ & 297(70.7) & $8^{\text {th }}$ \\
\hline 12 & $\begin{array}{l}\text { post malicious statements to defame } \\
\text { others in order to gain popularity }\end{array}$ & $109(26.0)$ & $311(74.0)$ & $11^{\text {th }}$ \\
\hline 13 & often give a wrong address & $145(34.5)$ & $275(65.5)$ & $4^{\text {th }}$ \\
\hline 14 & $\begin{array}{l}\text { pretend to be a female while I'm a male } \\
\text { when using social media }\end{array}$ & $123(29.3)$ & $297(70.7)$ & $8^{\text {th }}$ \\
\hline 15 & $\begin{array}{l}\text { usually, damage the reputation of anyone } \\
\text { that offends me through social media }\end{array}$ & $75(17.9)$ & $345(82.1)$ & $20^{\text {th }}$ \\
\hline 16 & $\begin{array}{l}\text { post the private details of another person } \\
\text { just for the gist }\end{array}$ & $107(25.5)$ & $313(74.5)$ & $13^{\text {th }}$ \\
\hline 17 & $\begin{array}{l}\text { give false information to emergency units } \\
\text { such as the address of a friend just to get } \\
\text { revenge }\end{array}$ & $90(21.4)$ & $330(78.6)$ & $15^{\text {th }}$ \\
\hline 18 & $\begin{array}{l}\text { do play pranks by giving false } \\
\text { information }\end{array}$ & $130(31.0)$ & $290(69.0)$ & $6^{\text {th }}$ \\
\hline 19 & $\begin{array}{l}\text { post nude pictures of my ex-partners, just } \\
\text { for the gist }\end{array}$ & $82(19.5)$ & $338(80.5)$ & $17^{\text {th }}$ \\
\hline 20 & post nude pictures of teenagers for fun & $77(18.3)$ & $343(81.7)$ & $19^{\text {th }}$ \\
\hline
\end{tabular}


Vol. 2, No. 1, Juni 2021

Hypothesis 1: Age, class level, gender, marital status, and religion would significantly influence the university undergraduates' expression on the prevalence of online harassment.

Table 3 reveals that the sum of squares for gender is 238.27 and the mean square is 238.27. The F-value (7.65) is significant at .006 $<.05$. The sum of squares for religion is 13.75 , and the mean square is 13.75 with the F-value of .44 and has the pvalue of .506 , which is greater than .05 levels of significance. The sum of squares for marital status and mean squares is 30.40 each with the F-value of .97 and p-value of.323 $>.05$ level of significance. The sum of squares and mean square for age is 25.85 each with the F-value of .83 and p-value of .362> .05 level of significance. The sum of squares and mean square for class level is 64.47 each with the F-value of 2.07 and has the p-value of $.151>.05$ level of significance. This result implies no significant difference in the prevalence of online harassment as expressed by the university undergraduates based on age, marital status, religion, and class level. However, a significant difference was found based on gender. It implies that male and female undergraduates have different views on the prevalence of online harassment among undergraduates. It could be that those female undergraduates experienced more online harassment than the males, as revealed in previous studies that disclosed significant gender differences in the online experience of males and females (Girlguiding, 2016; Henry \& Powell, 2016; Peterson \& Densely, 2017). The findings are not in line with that of Eckert (2017), who found no gender variation in the experience of online harassment. Undergraduates across religious beliefs, class levels, age, and marital status were similar in their views on the occurrence of online harassment. These findings are not in line with the findings and reports from Europe, the United Kingdom, and the United States on the experience of online harassment target at people of the Islamic faith as reported by Barlow and Awan (2016); Awan and Zampi (2015); United Kingdom Home Office, (2014); and Hall (2013).

Table 3. F-value Analysis of the differences among gender, age, marital status, religion, and class level on the prevalence of online harassment

\begin{tabular}{lccccc}
\hline \multicolumn{1}{c}{ Source } & $\begin{array}{c}\text { Type III Sum of } \\
\text { Squares }\end{array}$ & df & $\begin{array}{c}\text { Mean } \\
\text { Squares }\end{array}$ & $\begin{array}{c}\text { Calculated } \\
\text { F-value }\end{array}$ & p-value \\
\hline Correlated Model & $373.12^{\mathrm{a}}$ & 5 & 74.62 & 2.39 & .037 \\
Intercept & 26879.88 & 1 & 26879.88 & 864.02 & .000 \\
Gender & 238.27 & 1 & 238.27 & 7.65 & .006 \\
Religion & 13.75 & 1 & 13.75 & .44 & .506 \\
Marital Status & 30.40 & 1 & 30.40 & .97 & .323 \\
Age & 25.85 & 1 & 25.85 & .83 & .362 \\
Class Level & 64.47 & 1 & 64.47 & 2.07 & .151 \\
Error & 12879.59 & 414 & 31.11 & & \\
Total & 939999.00 & 420 & & & \\
\hline
\end{tabular}


SPEKTA

Jurnal Pengabdian Kepada Masyarakat : Teknologi dan Aplikasi

Vol. 1, No. 2, Juni 2021

\begin{tabular}{lll}
\hline Corrected Total & 13252.71 & 419 \\
\hline *Significant, $\mathrm{p}<.05$ &
\end{tabular}

Hypothesis 2: Age, class level, gender, marital status, and religion would significantly influence the university undergraduates' perpetration of various forms of online harassment.

Table 4 reveals that the sum of squares for gender is 652.68 , and the mean square is 652.68 with an F-value of 2.89 and has the p-value $=.090>0.05$ levels of significance. Based on religion, the sum of squares and the mean square is 7.86 each with the F-value of .03 and p-value of $.852>.05$ levels of significance. Based on marital status, the sum of squares and mean squares is .09 each with the F-value of .00 and $\mathrm{p}$-value $=.984>.05$ levels of significance. The sum of squares and mean square for age is 933.11 each with the F-value of 4.13 and has the p-value of $.043<.05$ levels of significance. The sum of squares and mean square for class level is 1960.32 each with the F-value of 8.68 and has the p-value of $.003<.05$ levels of significance. This result implies no significant difference in the forms of online harassment perpetrated by the university undergraduates based on gender, marital status, and religion. However, a significant difference was found based on age and class level.

Novo et al. (2014) had earlier found differences in the percentage of adolescents at various levels of education who perpetrated online harassment. On a similar note, Aizenkot and Kashy-Rosenbaum (2019) disclosed variation in the perpetration of cyberbullying across grade levels among Israeli students. Ybarra and Mitchell (2007) had earlier found age significant in the perpetration, while gender was not significant. The finding differs from Kowalski and Limber (2007), who reported that females were more involved in online harassment than males.

Table 4. F-value Analysis of the differences among gender, age, marital status, religion, and class level on the forms of online harassment perpetrated

\begin{tabular}{lccccc}
\hline \multicolumn{1}{c}{ Source } & $\begin{array}{c}\text { Type III Sum } \\
\text { of Squares }\end{array}$ & df & $\begin{array}{c}\text { Mean } \\
\text { Squares }\end{array}$ & $\begin{array}{c}\text { Calculated } \\
\text { F-ratio }\end{array}$ & p-value \\
\hline Correlated Model & $5171.01^{\mathrm{a}}$ & 5 & 1034.20 & 4.58 & .000 \\
Intercept & 14160.40 & 1 & 14160.40 & 62.76 & .000 \\
Gender & 652.68 & 1 & 652.68 & 2.89 & .090 \\
Religion & 7.86 & 1 & 7.86 & .03 & .852 \\
Marital Status & .09 & 1 & .09 & .00 & .984 \\
Age & 933.11 & 1 & 933.11 & 4.13 & .043 \\
Class Level & 1960.32 & 1 & 1960.32 & 8.68 & .003 \\
Error & 93398.11 & 414 & 225.59 & & \\
Total & 712520.00 & 420 & & & \\
Corrected Total & 98569.13 & 419 & & & \\
\hline
\end{tabular}

*Significant, $\mathrm{p}<.05$ 
Vol. 2, No. 1, Juni 2021

\section{CONCLUSION}

This inquiry offers support to the occurrence of online harassment among undergraduates. Over sixty-three percent of selected samples engaged in dog pilling, and forty-four percent perpetrated trolling online. Female and male respondents differ in their expression on the prevalence of online harassment, but females are like males in the perpetration of online harassment. Undergraduates differed in the forms of online harassment perpetrated across age and class levels. Gender, religion, and marital status were not significant in the respondent's reaction to the occurrence of online harassment, the forms of online harassment perpetrated.

The high rate of occurrence and perpetuation of online harassment calls for urgent attention of university administrators, professionals across fields of education, counseling, law, religion, and information and communication technologies to develop prevention strategies and deal with online harassment of various forms in Nigerian universities. Further studies on the rate of victimization and impacts of online harassment are fundamental to determining intervention direction.

\section{ACKNOWLEDGMENT}

Special appreciations to the university undergraduates at the eight faculties, their mutual understanding, and assistance while gathering data for this study are immeasurable. The university authority is also acknowledged for creating enabling environment to conduct the study.

\section{REFERENCES}

Aizenkot, D., Kashy-Rosenbaum, G. (2019). Cyberbullying victimization in WhatsApp classmate groups among Israel elementary, middle and high school students. Journal of Interpersonal Violence.

Andjelic, J. (2019). WhatsApps Statistics: revenue, usage, and history. https://fortunly.com/statistics/whatsapp_statistics.

Awan, I., Zempi, I (2015). We fear for our lives: offline and online experience of antimuslim hostility. https://tellmamauk.org/wp-content/upload/2017/05/We-Fear-ForOur-Lives.pdf .

Barlow, C \& Awan, I (2016). "You need to be sorted out with a knife": The attempted online silencing of women and people of Muslim faith within academia. https://doi.org/10.1177/2056305116678896. Social Media + Society 2, 1-11.

Chakraborti, N., Garland, J. (2015). Hate crime: Impacts, causes, and consequences. London: SAGE.

Duggan, M. (2017). Online Harassment. The Pew Research Centre (11 July 2017) https://www.pewresearch.org/internet/2017/07/11/online-harassment-2017/.

Eckert, S. (2017). Fighting for recognition: Online abuse of women bloggers in Germany, Switzerland, the United Kingdom, and the United States. New Media and Society P.14614444816688457.

Elias, J., Magdalena, P (2019). Google's rock path to email domination https://www.cnbc.com/2019/10/26/gmail-dominates-consumer-email-with-1point5billion-users.html.

Englander, E. (2017). Defining cyber-bullying. Pediatrics 140 (2), 148-151.

Feinberg, T., Robey, N. (2008). Cyberbullying. Principal Leadership. 9(1), 10-14. 
Vol. 1, No. 2, Juni 2021

$$
\begin{aligned}
& \text { Girl attitudes } \quad \text { survey } \\
& \text { https://www.girlguiding.org.uk/globalassets/docs-and-resources/research-and- } \\
& \text { campaigns/girls-attitudes-survey-2016.pdf. }
\end{aligned}
$$

Geach, N., Haralambous, N. (2009). Regulating harassment: Is the law fit for the social networking age? The Journal of Criminal Law

Hall, N. (2013). Hate Crime. London: Routledge.

Harris, A. (2013). Who Coined the Term Cat Fish.

Henry, N., Powell, A. (2016). Sexual violence in the digital age: the scope and limits. Criminal Law, Social and Legal Studies 25 (4), 397-418.

Home Office (2017). Statistical Bulletin.

Jenaro C., Flores, N., Vega, V., Cruz, M., Perez, M. C., Torres, V. A. (2017). Cyberbullying among adults with intellectual disabilities: Some preliminary data. Research in Developmental Disabilities, 72, 265-274.

Kennedy, M. A., Taylor, M. A. (2010). Online harassment and victimization of College Students. Justice Policy Journal 7(1), 2-21.

Khairi, A.N., Ma'ruf, F., Fitriani, S., Fahana, J. (2020). Sistem Informasi Keuangan Program Pengembangan Kewirausahaan FTI UAD. SPEKTA Jurnal Pengabdian Kepada Masyarakat: Teknologi dan Aplikasi 1(2), 55-64. https://doi.org/10.12928/spekta.v1i2.3087.

Kowalski, R. M., Limber, S. P (2007). Electronic bullying among middle-school students. Journal of Adolescence Health 41(1), 22-30. doi.org 10.1016/j.adohealth.2007.08.017.

MacDonald, C. D., Roberts-Pittman, B. (2010). Cyberbullying among students: Prevalence and demographic differences. Procedia-Social and Behavioral Sciences 9, 2003-2009.

Maltby, J. (2017). Implicit theories of online trolling: Evidence that attention-seeking conceptions are associated with increased psychological resilience. British Journal of Psychology, 448-466.

Muhinat, B.B. (2020). Educating Border Dwellers to Promote Peace and Security in an Electoral Process: Perception of Community Members', Zamfara State. SPEKTA Jurnal Pengabdian Kepada Masyarakat: Teknologi dan Aplikasi 1(2), 73-84.

Myers, C. A., Cowie, H., (2017). Bullying at university: the social and legal contexts of cyber-bullying among university students. Journal of Cross-Cultural Psychology, 48(8), 1172-1182.

Novo, F., Pereira, F., Matos, M. (2014). Cyber-aggression among Portuguese adolescents: A study on perpetration, victim-offender overlap, and parental supervision. International Journal of Cyber Criminology 8(2), 94-110.

Nigerian Communication Commission. (2019). Subscriber Statistics. https://www.ncc.gov.ng>statistic-reports>subscriber-data.

Nwachukwu, C., Onyenankeya, K. (2017). Use of smartphones among college students in Nigeria: revelation and reflections. DOI:10.1080/0976691X2017.1396007 https://www.researchgate.net/publication/322210927_Use_of_Smartphones_among _College_Students_in_Nigeria_Revelations_and_Reflections.

Ofcom Annual Report. (2017). Adults Media Use and attitudes. https://www.ofcom,org,uk.

Olumide, A., Adams, P., Amode, K. O. (2015). Prevalence and correlates of the perpetration of cyberbullying among in-school adolescents in Oyo state, Nigeria. 
Vol. 2, No. 1, Juni 2021

International Journal of Adolescents Medicine and Health 28(2). Doi:10.1515/ijamh-2015-0009.

Peterson, J., Densely, J. (2017). Cyber violence: What do we know and where do we go from here? Aggression and Violent Behaviour 34, 193-200.

Reports on ConsumerLab Trends and Insight. (2019).

Software Freedom Law Centre (SFLC, 2016) Online Harassment: A Form of Censorship. New Delhi: SFLC. in https://sflc.in/sites/default/files/wpcontent/uploads/2016/11/OnlineHarassment_SFLCin.pdf.

Annual Report (2018/19). University of Ilorin academic planning office. University of Ilorin, Nigeria.

Ybarra, M. L., Mitchell, K. J. (2007). Prevalence and frequency of Internet harassment instigation: Implications for adolescent health. Journal of Adolescent Health, 41, 189-195. doi:10.1016/j.jadohealth.2007.03.005.

Zachilli, T. L., Valiero, C. Y (2011). The knowledge and prevalence of cyberbullying in a college sample Journal of Scientific Psychology, 11-23. 